821.163.41.09-1 Петковић Дис В.

821.163.41.09-1 Миљковић Б.

https://doi.org/10.18485/msc_pred.2017.6.ch5

Предраг ПЕТРОВИЋ

Универзитет у Београду

Филолошки факултет

\title{
НАСЛЕЪЕ СРПСКОГ СИМБОЛИЗМА: ВЛАДИСЛАВ ПЕТКОВИЋ ДИС И БРАНКО МИљКОВИЋ
}

Познато Хајдегерово одређење језика као куће бивствовања, односно језика као медијума у коме се биће објављује човеку кроз свепрожимајуће значење онога што јесте, добило је свој смисаони наставак у Башларовом сликовитом одређењу поезије. У надахнуто написаној књизи Поетика простора Гастон Башлар пореди реч са малом кућом која има подрум и таван. Сваком спрату одговара одређени семантички ниво - у приземљу бораве она обична, у свакодневној комуникацији употребљива значења. Кренемо ли степеницама према врху постепено улазимо у сферу апстракције, а спуштајући се у подрум излажемо се опасности да се изгубимо у неосветљеним ходницима етимологије у којима су наталожена скривена језичка блага. „Пењати се и силазити у самим речима”, поентира Башлар, „то је песников живот. Песнику који земаљско повезује с надземаљским, допуштено је и да се превисоко пење и да предубоко силази."1

Било би занимљиво да следећи ову замисао, која и сама делује као песничка слика, говоримо о књижевницима који су склонији да активирају оне „више”, апстрактне сфере језика и попут Малармеа развијају поступке лирске апстракције и концепцију песништва које „жели да буде место на којем могу да се сретну апсолутно и језик"2, и, на другој страни, о ауторима уроњеним у дубине митског и архетипског, попут Јејтса који

\footnotetext{
${ }^{1}$ Gaston Bašlar, Poetika prostora, prev. Frida Filipović, Kultura, Beograd, 1969, str. 192.

${ }^{2}$ Хуго Фридрих, Структура модерне лирике, прев. Томислав Бекић, Светови, Нови Сад, 2003, стр. 102.
} 
је свој језик симбола нашао у митологији и херојским сагама Ирске, али и у окултизму свог времена. ${ }^{3}$

Заправо, оба ова усмерења, икарско и орфејско, део су јединственог поступка песничког стварања, алхемије речи која спреже рефлексивно и апстрактно са митским и архаичним. Песма настаје призивањем речи из што веће даљине, распоређених у креативном додиру логике (организоване песничке форме), семантике (неухватљиве многозначности) и музике (звучних и ритмичких квалитета остварених у споју гласова и речи). И превисоко успињање и предубоко спуштање дуж значењске и мелодијске вертикале речи могу дати исти резултат - песму која изазива недоумице и отежано разумевање, ону особену, херметичну песму која „зна тајну али је никада не каже". ${ }^{4}$

У сваком периоду новије српске поезије издвајају се аутори чији је песнички језик изразито обележен „пењањем и спуштањем у самим речима" и који стога образују један изузетан пример континуитета у нашој књижевности. У време романтизма у језички ковитлац био је зароњен Лаза Костић; у периоду модерне Дис је био више од свих опседнут мелодијом песничке речи и ирационалним понорима поетског сазнања; у авангарди се испитивању језичких могућности и границе која дели лирски израз од глухоте, посветио Момчило Настасијевић. Коначно, али не и на крају, на измаку педесетих година прошлог века огласио се још један трагач за „геолошким слојевима” и „потонулим градовима” које речи у себи носе, али исто тако и за могућностима лирске дематеријализације, сугестије и симболичког шифровања. Реч је о Бранку Миљковићу.

Миљковићево песничко и поетичко понирање у дубине језичког памћења значило је и неизбежан сусрет са нашим књижевним наслеђем и одређење према њему. Повратак старим песничким искуствима, поетичко, критичарско и теоријско самеравање односа поезије и традиције, (дис)континуитета савремености и наслеђа, елиотовских идеја и нашег песничког искуства једно је од кључних места књижевних разматрања током педесетих и шездесетих година прошлога века. Сва ова питања добила су своју најпотпунију дискурзивну артикулацију у текстовима Зорана Мишића а првенствено у његовој утицајној Антологији српске поезије (1956). У предговору „Један век српске поезије” он истиче једну изузетну линију у српском песништву чији су најизразитији носиоци управо Костић, Дис и Настасијевић. Оно што их повезује је „муцавост” њиховог језичког израза, „несавршеност” коју је академска естетика вредновала као знак ексцентричног, неозбиљног, те коначно неуспелог песничког подухвата.

\footnotetext{
${ }^{3}$ Види о томе: Нортроп Фрај, „Јејтс и језик симболизма”, Песничка митологија, прев. Тања Булатовић, Књижевна реч, Београд, 1999.

${ }^{4}$ Бранко Миљковић, „Херметичка песма”, Критике, прир. Сава Пенчић, Градина, Ниш, 1972, стр. 209.
} 
Насупрот том суду Мишић истиче: „Сви они који су имали нешто изузетно да кажу, који су грцали и запели у болном унутрашњем грчу пред неизрецивим, сламали су се о препреке које им је језик постављао."5 Управо та особита „несавршеност” чини њихове стилове јединственим и мелодијски препознатљивим. Пробијајући се кроз тамне вилајете у којима није увек лако повући јасну границу између говора и ћутања, облика и празнине, светлости и сенке они су, попут Орфеја, понели са тог путовања једино што се отуда могло изнети - песму.

Сва три поменута песника сусрешће се у Миљковићевом лирском циклусу „Седам мртвих песника” из збирке Узалуд је будим (1957). Међу духовним изабраницима, песниковом сабраћом са којима лирски субјект у овом циклусу успоставља везе, задржаћемо се на Дису, заправо сонету који је њему посвећен, али тим поводом занимаће нас и однос Дисове и Миљковићеве поетике - прва је само имплицитно назначена у особеној композицији збирке Утопљене душе, док је друга експлицирана и теоријски артикулисана у низу есеја и критика. Покушаћемо да међусобним осветљавањима песничких стратегија једног симболисте с почетка прошлог века и једног аутора који је близак неосимболизму, уочимо сродности њихових стваралачких опсесија, као и присуство Дисовог искуства у српском песништву XX века, па тиме и постојање особите орфејске линије у нашој новијој поезији.

Проучаваоци Миљковићеве поетике приметили су да неосимболисти у својом програмским текстовима не одређују прецизно свој однос према српском симболистичком наслеђу. ${ }^{6}$ Ставови које је Миљковић износио у својим есејима о потреби за строгим песничким облицима као услову песничке уметности, могли би се довести у везу са „кабинетским радницима и ученим занатлијама на тешком послу риме и ритма”, како је песника описао Дучић, који су српски везани стих и песничку форму довели до завидног уметничког нивоа. Миљковић се, међутим, углавном позива на француске симболисте - Малармеа, Рембоа, Верлена, а од српских помиње једино Диса, који свакако не задовољава високе захтеве за савршеном формом језика, бар не на онај начин како је то захтевала естетика Богдана Поповића на почетку прошлог века. Својим огрешењима о синтаксу, логику и стих Дис отвара путеве разградњи наше парнасо-симболистичке поезије и њеног формалног савршенства. Управо „муцавог”, „немарног” Диса и његову „декадентну” поезију помиње Миљковић када говори о српском симболизму. У познатом интервјуу из 1960. године („Ајнштајн се може препевати”) Миљковић истиче две песме - „Santa Maria della

\footnotetext{
${ }^{5}$ Zoran Mišić, Antologija srpske poezije, četvrto izdanje, Nolit, Beograd, 1983, str. XIII.

${ }^{6}$ Види о томе : Александар Јовановић, Поезија српског неосимболизма, Филип Вишњић, Београд, 1994.
} 
Salute” Лазе Костића и Дисову „Можда спава”, као најлепше у нашој поезији. ${ }^{7}$ Ову двојицу једно време оспораваних песника довешће у везу и у тексту „Лаза Костић и ми”, битном за Миљковићево одређење према књижевној традицији. У првим реченицама одлучно се констатује: „Да нам романтизам није дао једног Лазу Костића, а симболизам једног Диса, данас би једна генерација врло талентованих песника била, добрим делом, антитрадиционалистичка и нихилистичка. Надреализам, који се са више или мање права поиграо са дотле утврђеним књижевним вредностима, није ни покушао да се поигра са једним Дисом и Лазом Костићем." ${ }^{\prime 8}$ Миљковић афирмише Костића и Диса као величине на којима почива веза између наше песничке традиције и модерних аутора. До првог озбиљнијег превредновања односа према Костићу и Дису дошло је баш у време авангарде која је оспоравала Дучића или Ракића а величала управо песнике којима су Поповић и Скерлић негирали књижевни таленат. О томе сведочи и суд Момчила Настасијевића да је управо Дис врх српске поезије из времена модерне зато што је његова поезија „право мистично ћутање” припадајући „најдубљим, најмистичнијим стварима наше лирике”. ${ }^{9}$ Готово да није ни потребно нагласити у којој мери је оваквом оценом о Дису Настасијевић одредио и сопствену поетику.

Међутим, вратимо се одговору на питање зашто је Бранко Миљковић баш у Дису видео врх српског симболизма. Најпре због тога што је Дисовом поезијом српска лирика напустила линију „ниског” симболизма (парнасо-симболизма) и уздигла се ка „високом” симболизму који почиње од Бодлера а свог најизразитијег представника добија у Малармеу. Који су то квалитети Дисове поезије који га приближавају овој песничкој линији европске лирике и поред све његове „муцавости” и „расејаности”? У есеју „Орфејско завештање Алена Боскеа” Миљковић као једну од кључних одлика добре песме истиче моменат неизрецивости и наставља: „Намера песника је да каже неизрециво. Али пошто је неизрецивост јача од песника, она преузима његову намеру и према њој се понаша слободно. [...] песма и песник врло брзо замене своје улоге. Песник уместо да каже бива казан. Да би задржао своје право на реч, песник је принуђен да постане објекат поезије. Уместо да песник пише поезију, поезија пише песника."10

\footnotetext{
${ }^{7}$ Бранко Миљковић, Критике, стр. 260.

${ }^{8}$ Бранко Миљковић, Критике, стр. 118. Костића и Диса довео је у везу и Јован Скерлић, али као примере „књижевног глумачења” и одсуства сваког песничког талента: „Владислав Петковић Дис, то је Лаза Костић који је, задоцнивши за читава пола века, залутао у Београд” (Јован Скерлић, „Лажни модернизам у српској књижевности”, Писиии и књиге, књ. V, Просвета, Београд, 1964, стр. 83).

${ }_{9}^{9}$ Момчило Настасијевић, Есеји, белешке, мисли, прир. Новица Петковић, Српска књижевна задруга, Београд, стр. 456.

${ }^{10}$ Бранко Миљковић, Критике, стр. 193. Иако је овде не помиње, Миљковић свакако има на уму чувену Рембоову изјаву из писма Жоржу Изамбару (1871): „Нетачно је рећи:
} 
Напор да се искаже неизрециво, оно што је Настасијевић назвао мистичним ћутањем, пред понорима ирационалног, поетичка је доминанта Дисове поезије. С правом је Дис зато назван првим нашим песником „проклетства неизрецивог”. ${ }^{11}$ Повлачење пред стварним, материјалним светом и његовом рационалном логиком у свет ирационалних визија и сновиђења изражено је у Дисовој поезији напуштањем језичке, односно синтаксичке правилности (одустајање од оне синтаксе коју је Дучић одредио „геометријом мисли”) и развојем особеног песничког израза, „мутног, сибилског”, како је оценио Скерлић, заснованог на индивидуалној песничкој граматици.

Однос ирационалног и несвесног према језику и писму једна је од кључних преокупација у текстовима аутора из кругова савремене психоанализе и семиотике. У једном од својих познијих радова Јуриј Лотман разматра положај културе сна и његових тумача у архаичном и модерном друштву, од шамана до психоанализе. Посматрајући функцију сна у сфери комуникације, свакодневне али и уметничке, Лотман сан одређује као семиотичко огледало у коме свако види одраз свог неодређеног и тајанственог језика. Као необично крхко и вишезначно средство за чување информација, „резервоар семантичке неодређености” сваки сан је на првом месту дубоко индивидуалан али и у дослуху са колективном мрежом симбола. Зато постоји максимална потешкоћа у комуникативности тог језика - „препричати сан исто тако тешко је као што је тешко препричати речима музичко дело."12 Али баш ти недостаци чине да сан има повлашћено место у култури, а поготову у уметности и књижевности којима је сан иманентан због свог језика неодређености и симболичких простора који се могу испунити различитим значењима.

Довођење у везу сна са језиком неодређености и, што је посебно важно, са структуром музичког дела, битно је за тумачење Дисове поезије и њеног више флуидно сугестивног него појмовно заснованог језичког израза. На преокрет који је настао у Дисовом песничком језику и сликама, управо упућује цитирани одломак из Миљковићевог текста о Алену Боскеу. У жељи да искаже неизрециво, песник, односно лирски субјект временом постаје песнички објекат - уместо да казује, бива казан. Новија тумачења Дисове поезије потврђују овај Миљковићев став о неминовности замене места песничког субјекта и објекта као једном и од ступњева

мислим. Требало би казати: мишљен сам" (Artur Rembo, Sabrana poetska dela, prev. Nikola Bertolino, Paideia, Beograd, 2004, str. 263). Овај обрт у логици и синтакси за који се залаже Рембо, добиће далекосежни одјек у модернистичкој поезији.

${ }^{11}$ Предраг Палавестра, Историја модерне српске књижевности, Српска књижевна задруга, Београд, 1995, стр. 313.

${ }_{12}$ Jurij Mihajlović Lotman, „San - semantički prozor”, Kultura i eksplozija, prev. Dobrilo Aranitović, Narodna knjiga, Beograd, 2004, str. 202. 
у самоеманципацији и осамостаљивању песме. Обртање оног језгреног синтаксичког односа између агенса и пацијенса, тако да у Дисовој песничкој слици свет постаје активан, а песнички субјект пасиван, средиште је Дисове поетике. ${ }^{13}$

У Миљковићевом есеју посвећеном поезији Стевана Раичковића, „Песма и смрт”, присутно је још једино могуће, имплицитно комуницирање са Дисовом поезијом и поетиком. „Од симболизма наовамо”, пише Миљковић, „преосетљиви песници сањају о песми без речи”. ${ }^{14}$ У Дисовој брижљиво компонованој збирци Утопљене душе, у циклусу „Тишине”, налази се песма која се управо тако и зове - „Песма без речи”. Речи које својим конвенционалним облицима и значењима не могу да изразе тамне визије које долазе из сећања и сна, распадају се, а уместо њих наступа слутња и тишина:

„Видим неку силуету тавну,

Траг прошлости, залазак сећања

И све речи да с обликом стају

Ту, преда ме, где се распадају."

Као резултат таквог распадања речи следи наредни циклус - „Недовршене речи” који, судећи према насловима и редоследу песама („Прва песма”, „Трећа песма”, „Седма песма”), делује као остатак после распадања неке веће целине, циклус у којем преовлађују песме којих нема, где празнине и маргине тишине надвладавају над оним што је написано.

Иако се Дисове песме, за разлику од многих Миљковићевих, не могу назвати херметичним, у њима препознајемо многе елементе које је Миљковић истицао и на којима је заснивао своју поезију - слутња, неизрециво, дематеријализација, те коначно празнина и заборав. Позивајући се на француског песника Жила Сепервјела и његово схватање „заборављеног сећања", Миљковић у низу есеја говори о забораву као битном моменту модерне поезије: „Оно што песма хоће да каже мора да буде оно што песма тражи, оно што се у њој изгубило. Песма је заборав и од заборава. Она не казује садржај већ мутно досеже.” Или, да наше наслућивање везе са Дисовом песмом „Можда спава” буде наглашеније: „Сваку песму треба заборавити да би постојала, јер поезија и музика одигравају се иза нас." 15 Тиме се, између осталог, да објаснити Миљковићево истицање ове Дисове песме - заборав је поменут већ у првом стиху и води постепеној дематеријализацији свега реалног и померању песничког бића у пределе

\footnotetext{
${ }^{13}$ Види о томе: Новица Петковић, „Дисов језик, слике и музика стиха”, Огледи о српским песницима, Друштво за српски језик и књижевност, Београд, 2004.

${ }^{14}$ Бранко Миљковић, Критике, стр. 116.

${ }^{15}$ Исто, стр. 218.
} 
слутње и сна. Заборав тако постаје поетички повлашћено место лирске одсутности у којем никакво несавршенство оптичког опажања не угрожава чистоту духовног виђења. Песма „Можда спава” почиње поетским искуством заборава које стварима одузима материјалност и омогућава им да засијају у новој, уметничкој димензији речи, музике и сна. ${ }^{16}$

Говорили смо о односу Дисове поезије и Миљковићевих поетичких ставова, не због тога да бисмо доказивали неке могуће утицаје и пуку подударност, већ да истакнемо да је Дисова поезија у српско песништво унела читав низ категорија и поступака који ће од тада постати поетичке доминанте током целог прошлог века српске лирике, а чије изворно порекло треба тражити у поезији француског високог симболизма, првенствено код Малармеа. И Дис и Миљковић, свако на свој начин и у духу свог времена, опседнути су сличним стваралачким изазовима и ограничењима, па укрштање њихових поетичких вертикала може допринети бољем осветљавању њихових песничких остварења.

Непосредни повод за уочавање веза између ова два аутора је песма „Дис” из циклуса „Седам мртвих песника”. Међутим, то није прва песма посвећена трагично настрадалом симболисти. Прву је, под насловом „Дису”, неколико дана након његове смрти, испевао Стеван Бешевић, у Српским новинама на Крфу 1917. године. ${ }^{17}$ Овде је помињемо због једне изразите сличности са Миљковићевом песмом - и једна и друга су у знаку Дисове трагичне смрти, у водама Средоземља, и приказују мртвог песника на морском дну (у Бешевићевој песми: „Док ти на дну лежиш у царству сирена / И шкољка Тротона кроз бездане труби"). Трагично укрштање књижевне (Утопљене душе) и животне чињенице у Дисовом, као уосталом и у Миљковићевом случају остала је до данас битан моменат за рецепцију њихове поезије, као и за плетење легенди о њиховим животима. Као да је у њиховом случају песма нашла своју потврду и остварење у смрти самог аутора. ${ }^{18}$

У том смислу Миљковић са седморицом мртвих песника у истоименом циклусу успоставља песничку везу следећи и делећи не само њихове

\footnotetext{
${ }^{16}$ Проницљиво анализирајући удео „уметности и критике заборава” у формирању европске духовности од античких времена до данас, немачки хуманиста Харалд Вајнрих издваја „поезију заборава” као ону линију модернистичког песништва која претечу има у Малармеу за кога је „заборав суштински услов поетског стања” (Harald Vajnrih, Leta: umetnost i kritika zaborava, prev. Drinka Gojković, Fabrika knjiga, Beograd, 2008, str. 253).

${ }^{17}$ Српске новине, 20. мај 1917, LXXXIV/60, стр. 3. песма је потписана словом С. Прештампана је затим у издању Дисових Скупљених песама, Београд, 1921, стр. 16.

${ }^{18} \mathrm{O}$ критичарском проблему подударања песничког и личног писао је Норторп Фрај у свом есеју о Бајрону. Узимајући овог романтичарског песника као изразити пример, Фрај истиче: „Бајрон доказује оно што многи критичари проглашавају немогућим: да једна песма може вршити утицај као историјски и биографски документ” (Нортроп Фрај, „Лорд Бајрон”, Песничка митологија, стр. 130).
} 
поетичке, већ и животне опсесије и трагедије. У песми „Дис” то је водена смрт, морска дубина у коју је утонуло Дисово песничко биће и људско тело, сабласни водени простор настањен тишином, мраком и самоћом. Огромна вода која окружује Дисово биће у Миљковићевој песми је космос смрти. „Имагинација несреће и смрти налази у воденој материји посебно снажну и природну материјалну слику. [...] За извесне сањаре вода је космос смрти," пише Башлар. ${ }^{19}$

Такав доживљај воде као симбола смрти присутан је у Дисовим песмама. Једна од најпознатијих је слика мртвог мора из „Нирване”: „Ноћас су ме походила мора / Сва усахла, без вала и пене.” Слика мртвог, односно мирног мора, утопљених душа и тоњења, појављује се у низу Дисових песама. У „Плавим мислима” сама смрт добија облик воде - смрт ће опрати трагове од рана, а у песми „Са заклопљеним очима” гроб је представљен као пуста кућа мирног, мртвог мора. Такав доживљај воде има дубоко митско порекло („Није ли смрт била први морепловац?” пита се Башлар), а видећемо да је то случај и са неким другим Дисовим сликама и симболима. Мотив воде, односно „ирационална политика вода” коју Миљковић помиње у свом есеју о Душану Матићу, битан је за разумевање блискости два песника. У истом есеју, говорећи о Матићевој песми „Море”, Миљковић констатује: „У овој песми Матић као да је допевао на бретоновски начин две најлепше Дисове песме: 'Можда спава' и 'Утопљене душе'.'20 Коначно, сам Миљковић има низ песама посвећених води и мору. Оно је приказано као водена стихија заљубљена у бродоломе (песма „Море без песника") која у исти мах и разара и ствара. Дисово море је само дубина у коју се тоне, материјализација нирване која све потапа тишином. Међутим, вода је, проговара Дисов лирски глас у Миљковићевом сонету, ипак боља од земље којом рије црв, јер ,jедино вода може да спава и да сачува лепоту; једино вода може да умре, непомична, и да сачува своје одблеске", ${ }^{21}$ за разлику од грозног распадања у земљи које Дис приказује у „Њено име” и другим песмама.

То није једина интертекстуална веза уочљива у Миљковићевој песми „Дис”. Већ у првом стиху („О моје сунчано порекло па потонула крв”) присутно је супротстављање по вертикали горе-доле, небеске висине-зе-

\footnotetext{
${ }^{19}$ Гастон Башлар, Вода и снови: огледи о имагинацији материје, прев. Мира Вуковић, Издавачка књижарница Зорана Стојановића, Сремски Карловци, Нови Сад, 1998, стр. 118.

${ }^{20}$ Бранко Миљковић, Критике, стр. 127.

${ }^{21}$ Гастон Башлар, Вода и снови, стр. 90. Харалд Вајнрих доводи у везу стање заборава с култом мртвих који репрезентује вода. „Лета је пре свега име реке из Доњег света, која душама умрлих даје заборав. У тој слици и сликовном пољу заборав је сасвим уроњен у течни елемент воде. У симболици те магичне воде лежи дубоки смисао. Оштре контуре сећања на стварност растварају се у њеном меком току и на тај начин бивају ликвидиране" (Harald Vajnrih, Leta: umetnost i kritika zaborava, str. 24).
} 
маљска, односно морска празнина. Миљковић се не задржава само на увођењу Дисовог поимања живота као пада с невиних даљина, већ удвајањем лирског гласа песнички се надовезује и допуњује Дисову визију небеске преегзистенције и човековог кобног пада: „Ако смо пали били смо паду склони". Схватање живота као пада присутно је и у Миљковићевој поезији, али засновано на знатно сложенијим, егзистенцијалистичким филозофским поставкама.

Задржимо се на крају на још једној битној вези између Диса и Миљковића, оној која најбоље осветљава природу њиховог орфејског певања. Реч је о мотиву мртве, односно уснуле драге.

У Дисовој песми „Можда спава” драга је потпуно дематеријализована, борави само у пределу сна и слутње, музике и сећања. Њен живот, односно смрт, постоје за лирског субјекта као неразрешени преплет могућности - можда живи / можда почива, на граници тренутног и вечног сна. Реч је о стању које Башлар одређује на следећи начин: „Нове психологије несвесног уче нас да су за наше несвесно, и све док остају међу нама, мртви заправо спавачи. Они почивају. После сахране, за то исто они су само одсутни, скривенији, успаванији спавачи. Из сна се буде тек када ми сами уснимо неки сан који је дубљи од успомене; када се са несталима нађемо у постојбини ноћи." 22 Таквом доживљају мртве, односно уснуле драге најприближније одговара архетипска, заправо бајковита слика успаване лепотице. Управо таква слика постоји у Дисовој песми „Гробница лепоте”, која је једна могућа рана варијанта песме „Можда спава”, првенствено због завршних стихова:

„Место црви - мртво цвеће, мртве дуге

По њој: она спава, с њом њена лепота."

Песма „Гробница лепоте” у целини има бајковит сиже - незнана лепотица живи у далекој земљи дуге и пролећа. Али изненада ветар доноси јесен и са смрћу природе одлази и лепа девојка, падајући у сан („Заспале су благо њене очи дана"). Очигледно да ова песма прелаз из живота у смрт, која је поистовећена са сном, повезује с још једним битним архетипским извором који може бити од значаја за тумачење мотива мртве драге код Диса, а то је календарски циклус смене годишњих доба. ${ }^{23}$

Док је у Дисовим песмама, првенствено у песми „Можда спава”, мит о Орфеју и Еуридици присутан само као архетипско језгро мотива мртве

${ }^{22}$ Исто, стр. 88.

23 Значај природног циклуса за организовање слика и симбола у песништву истиче Нортроп Фрај, који у виду општег закључка вели и ово: „Смена годишњих доба, дана и ноћи, периода живота и смрти, помогли су да се литератури пружи комбинација кретања и реда, промене и сталности, што је потребно свим уметностима” (Нортроп Фрај, „Нови правци из старине", Песничка митологија, стр. 59). 
драге, код Миљковића је митски сиже сасвим јасно уткан у садржај песме, али и поетски транспонован и симболички надграђен. У „Триптихону за Еуридику" код Орфеја, као и код Дисовог песничког субјекта, постоји нада, могућност да је смрт заправо сан: „Пробудити те морам Еуридико мртва.” Међутим, док у Дисовој песми тајна није разрешена до краја, у завршном делу „Триптихона” свест о поразу и губитку недвосмислено је присутна: „Изгубио сам те у ноћи подземној далеку.” Али то је губитак само материјалног, телесног облика појављивања. Попут Дисове драге, Еуридика остаје у песми („Где си осим у мојој песми дивна Еуридико?”) која помера границе смрти, спаја два света која су до тада била неумољиво раздвојена. Орфеј није извео своју Еуридику на светлост дана, али јесте у своју песму и у језик, победио је оно пред чим смртници занеме, постајући тако први сведок поезије и говорник против смрти и против немости, како га назива Петер Слотердајк. „Са Ерудиком међу сенкама он стиче искуство које остаје важеће за сваку литературу која се излаже. Докле год је он из поетске жудње води за собом према дану, према светлу, према језику, доклегод се не окреће да би је запосео, дотле побеђује оно што људе иначе чини немим и наводи покоравању пред смрћу."24

Скерлић је Утопљене душе сасвим тачно назвао програмском књигом наше нове уметности. Она ће током читавог прошлог века то и остати за неколико генерација српских песника. Миљковићев лирски дијалог са Дисовом поезијом свакако није завршетак орфејског понирања у дубине песничког и егзистенцијалног бића.

\section{ИЗВОРИ}

Миљковић 1972: Б. Миљковић, Критике, (прир. Сава Пенчић), Ниш: Градина.

Миљковић 2001: Песме, (прир. Новица Петковић), Сремски Карловци: Каирос.

Настасијевић 1991: М. Настасијевић, Есеји, белешке, мисли, (прир. Новица Петковић), Београд: Српска књижевна задруга.

Настасијевић 1991: М. Настасијевић, Поезија, (прир. Новица Петковић), Београд: Српска књижевна задруга.

\footnotetext{
${ }^{24}$ Peter Sloterdajk, Tetovirani život, prev. Milan Soklić, Dečje novine, Gornji Milanovac, 1991, str. 35.
} 


\section{ЛИТЕРАТУРА}

Bašlar 1969: G. Bašlar, Poetika prostora, (prev. Frida Filipović), Beograd: Kultura.

Башлар 1998: Г. Башлар, Вода и снови: огледи о имагинацији материје, (прев. Мира Вуковић), Сремски Карловци, Нови Сад: Издавачка књижарница Зорана Стојановића.

Vajnrih 2008: H. Vajnrih, Leta: umetnost i kritika zaborava, (prev. Drinka Gojković), Beograd: Fabrika knjiga.

Јовановић 1994: А. Јовановић, Поезија српског неосимболизма, Београд: Филип Вишњић.

Lotman 2004: J. M. Lotman, Kultura i eksplozija, (prev. Dobrilo Aranitović), Beograd: Narodna knjiga.

Mišić 1983: Z. Mišić, Antologija srpske poezije, četvrto izdanje, Beograd: Nolit.

Палавестра 1995: П. Палавестра, Историја модерне српске књижевности, Београд: Српска књижевна задруга.

Петковић 2004: Н. Петковић, „Дисов језик, слике и музика стиха”, Огледи о српским песницима, Београд: Друштво за српски језик и књижевност.

Rembo 2004: A. Rembo, Sabrana poetska dela, (prev. Nikola Bertolino), Beograd: Paideia.

Скерлић 1964: Ј. Скерлић, Писичи и књиге, књ. V, Београд: Просвета.

Sloterdajk 1991: P. Sloterdajk, Tetovirani život, (prev. Milan Soklić), Gornji Milanovac: Dečje novine.

Фрај 1999: Н. Фрај, Песничка митологија, (прев. Тања Булатовић), Београд: Књижевна реч.

Фридрих 2003: Х. Фридрих, Структура модерне лирике, (прев. Томислав Бекић), Нови Сад: Светови. 